\title{
Edgar N. Weaver, Jr.: Surgical care of the painful degenerative lumbar spine: evaluation, decision-making, techniques
}

\section{Thieme Verlag, New York, Stuttgart, Delhi, Rio de Janeiro, 2018, 152 pp, 74 figs., Softcover, EUR (D) 49,99 EUR (A) 51,40 CHF 57,00, ISBN: 978-1-62623-806-0}

\author{
Pierre H. Kehr ${ }^{1}$
}

Received: 10 July 2019 / Accepted: 20 July 2019 / Published online: 25 July 2019

(c) Springer-Verlag France SAS, part of Springer Nature 2019

Sir William Osler's sentence: "The good physician treats the disease. The great physician treats the patient who has the disease," placed at the top of the introduction of the book announces from the outset the importance given by the author to the human relationship of the surgeon with his patient. The understanding of the experience of pain must be appreciated and placed in its emotional context, which can lead to a depressive state that will potentially interfere with our therapeutic decision.

An important anatomical and biomechanical reminder of the lumbosacral hinge, abundantly illustrated, follows. The importance of radiculalgy must be assessed. A large chapter (No. 6) now describes all decompression techniques, also very well illustrated by diagrams. Follows a chapter (No. 7) dedicated to the lateral stabilization L3-sacrum. Minimally invasive surgery techniques occupy a big chapter (No. 8).
The book concludes with a chapter devoted to the complex cases and socio-economic repercussions of these surgeries. Book to advise neurosurgeons and orthopedic surgeons confronted with the surgical indications of so frequent lowback pain and lomboradiculalgy.

\section{Compliance with ethical standards}

Conflict of interest The authors declare that he/she has no competing interests.

Publisher's Note Springer Nature remains neutral with regard to jurisdictional claims in published maps and institutional affiliations.
Pierre H. Kehr

pierre.kehr@gmail.com

1 Strasbourg, France 